\title{
Eltérő városi útdíj-struktúrák hatásának vizsgálata
}

\begin{abstract}
A lehetséges városi útdíjfizetési stratégiák összehasonlítását Budapestre vonatkozóan a kordonalapú rendszer részletes vizsgálatából ismerhetjük meg. Jó esély az összehasonlításra, hogy ehhez képest milyen jellemzőket mutat a távolságalapú, az időalapú, illetve a késési idő alapú útdíjfizetési stratégia.
\end{abstract}

DOI 10.24228/KTSZ.2018.6.3

\section{Tóth Tamás - Török Ádám}

BME Közlekedésüzemi és -gazdasági Tanszék

e-mail: 59tomi@gmail.com, atorok@kgazd.bme.hu

\section{BEVEZETÉS}

A városi útdíjak témaköre a külföldi szakirodalomban régóta mélyen vizsgált téma [1] [2], amelynek legfontosabb célja eredetileg a közlekedés externális hatásainak szabályozása. Erre a legjobb elméleti megoldás a Pigou által leírt [3] határköltség alapú díjfizetés. Ennek feltételei ugyanakkor a valóságban nem állnak rendelkezésre, így az ún. második legjobb megoldások kerültek gyakorlati alkalmazásra, amelyeket összefoglalóan de Palma és Lindsey [4] mutatott be.

Magyarországon a városi útdífizetés elméleti hátterével Erhart Szilárd [5], Juhász Mattias [6], Monigl János és munkatársai [7], [8] foglalkoztak, majd a Városkutatás Kft. [9], [10], illetve a Budapesti Közlekedési Központ megbízásából a Trenecon-Cowi Kft. készítettek tanulmányokat [11] a lehetséges gyakorlati alkalmazásra vonatkozóan a főváros számára. Hazánkban ezek a dokumentumok foglalkoztak legrészletesebben a „dugódíj” elméleti és gyakorlati kérdéseivel, azonban ezekben a tanulmányokban alapvetően kordonalapú rendszerek vizsgálatáról van szó, alternatív megoldások nem kerültek részletes elemzésre.
Külföldi kutatásokban is kiemelt szerepet kapnak a kordonos rendszert érintő vizsgálatok, illetve szintén több kutatás foglalkozott a távolságalapú díjrendszerrel is. Számos esetben különbözö kritériumok szerinti rendszeroptimumot kerestek akár a díj mértékére, akár a díjszedés helyére vonatkozóan [12]. Verhoef [13] gráfelméleti megközelítésen alapuló hálózaton vizsgálta az ún. második legjobb megoldásokat általános - hálózati topológiától és díjrendszertől független - módon. Zhang és munkatársai [14] a kordonalapú és zónarendszerủ díjak hatását vizsgálták az igényekre, illetve a szerzők a díjrendszerek területi lehatárolásának optimalizálására (fizetős szakaszok, kordonpontok meghatározása) alakítottak ki eljárást. May és Milne [15] cikkében négy különböző (kordonos, távolságarányos, időalapú és késési idő alapú) útdíj stratégiát vizsgált Cambridge városának hálózatán, amely egy - szintén az ő nevükhöz füződő - későbbi tanulmány [16] alapját képezi. Ez utóbbiban a továbbfejlesztett modellt York és Leeds városára is alkalmazták, a három vizsgált angliai városra vonatkozó eredményeket pedig összehasonlították.

A kordon rendszerü dífizetés esetében egy kijelölt városi területet kordonnal határolnak le, 


\section{Városi közlekedés}

és az ezen történő áthaladás vonja maga után a díjfizetési kötelezettséget. Norvég városokban (például Trondheimben) már a 90-es évek elején bevezették a kordonalapú útdíjfizetést, meghatározott időre és bevételtermelési céllal. Szakmai körökben jól ismert a 2007-ben népszavazás által jóváhagyott stockholmi kordonalapú fizetési rendszer, amelynek célja a forgalom szabályozása és az igények befolyásolása volt [17].

A zóna rendszerü díjfizetés esetében a kordonalapúval szemben nem csak a kijelölt területre a behajtást, hanem a belső területen való közlekedést is lehet útdíjjal szabályozni. Ez a kordonoshoz képest eltérő technológiai megoldásokat igényel az ellenőrzés területén is, hiszen a kizárólag a belső területen lebonyolódó forgalmat is ellenőrizni kell. Londonban 2003 óta müködik zónás városi útdíjfizetési rendszer, amelyet 2007-ben kiterjesztettek nyugati irányba, így a legnagyobb kiterjedésü városi útdíjfizetési rendszerek közé tartozott. Ezt az intézkedést 2011 januárjában visszavonták.

A városi környezetben a zónaalapú rendszerben a díjképzés fix dijak helyett történhet változó díjakkal is, amelynek alapját különböző tényezők jelenthetik. A távolságarányos díjfizetési rendszer esetében a fizetendő összeget a megtett távolság függvényében fizeti a felhasználó, amely függvény nem feltétlenül kell, hogy lineáris legyen. A távolságalapú rendszerek jellemzően az országos közúthálózatokon müködnek, városi körülmények között ma még nem alkalmazzák ezt a megoldást [18].

Az időalapú díjak számítása a felhasználók tényleges eljutási ideje alapján történik, tehát az aktuális körülményektől függően változik a díj mértéke. A rendszer alkalmazása azonban több problémát is felvet. Egyfelöl, a zónán belül parkolással töltött időt szükséges elkülöníteni az utazással töltött időtől, hiszen erre teljesen más díjtételek vonatkoznak. Másfelől pedig, közlekedésbiztonsági oldalról aggályos lehet, hogy az időalapú díjazás a felhasználókat siettetésre késztetheti. Ezt a problémát a modellezés során nem tudtuk figyelembe venni, ezért feltételeztük, hogy minden jármüvezető a forgalmi körülmények alapján választja meg a sebességét.
A valóságban az időalapú díjszámítások társadalmi elfogadottsága kérdéseket vethet fel, hiszen a különböző haváriák nagyban befolyásolhatják a fizetendő összeget. Baleset vagy akár a közútkezelő oldalán felmerült műszaki probléma (pl. jelzőlámpa meghibásodás) értelemszerüen lassítja az eljutást, az emiatt fizetendő többletösszeget a felhasználók igazságtalannak érezhetik. Ez esetben az utólagos kezelés és díjvisszatérítés jöhet szóba, ami azonban valós szándék esetén, bevezetés előtt, mindenképpen egy további vizsgálatot igénylö terület lenne.

\section{METODIKA - A MAKROSZKOPIKUS FORGALMI MODELL KIALAKÍTÁSA}

Cél a bevezetőben ismertetett díjstruktúrák összehasonlítása forgalmi szempontból, amely egy kétéves kutatási folyamatra épült. A vizsgálat végrehajtásához a legalkalmasabb eszköz egy városi forgalmi modell, amelyet először Excelben és Javaban megírt számítások segítségével hoztunk létre, majd a kutatás második évében már a kifejezetten erre a célra kifejlesztett Visum szoftvert alkalmaztuk, amelyet a gyártó PTV kutatási céllal díjmentesen a rendelkezésünkre bocsátott.

A vizsgálat négy fö részből állt, amelyek esetenként további alrészekre bonthatók. Kezdő lépésként szükséges volt az alapállapothoz tartozó modell elkészítése, amely magában foglalja a hálózati és az igénymodellek elkészítését, valamint szorosan összefügg a következő lépéssel, ami a hatásmodell kialakítása. A hatásmodell gyakorlatilag a modell beépített eljárásainak (ráterhelések, mátrixok kezelése, stb.) megfelelően kialakított rendszer, amelynek célja, hogy a felhasználók útdíjra adott reakcióját leképezze.

Külön lépésként szerepel a szcenáriók meghatározása, mivel az eltérő alapelven müködő díjstruktúrák összehasonlíthatóvá tétele is önálló vizsgálatot igényelt.

A modell közúti alrendszerében az úthálózati szakaszokat korábbi kutatásainkat [18] alapul véve öt fö csoportba soroltuk, de az alkalmazott kapacitásértékeket a gyakorlat- 


\section{Városi közlekedés}

\begin{tabular}{|c|c|c|c|}
\hline Csoport & Díjstratégia megnevezése & Díjfizetés alapja & Dimenzió \\
\hline \multirow{2}{*}{$\begin{array}{l}\text { Statikus, } \\
\text { forgalomtól független díjak }\end{array}$} & Kordonalapú behajtási díj & Behajtás (fix költség) & [Ft/behajtás] \\
\hline & Távolságalapú, zóna rendszerủ díj & Megtett út (változó költség) & {$[\mathrm{Ft} / \mathrm{km}]$} \\
\hline \multirow{2}{*}{$\begin{array}{l}\text { Dinamikus, } \\
\text { forgalomtól függő díjak }\end{array}$} & Időalapú, zóna rendszerü díj & Utazási idő (változó költség) & {$[\mathrm{Ft} / \mathrm{s}]$} \\
\hline & $\begin{array}{l}\text { Késési időtöbblet alapú, zóna } \\
\text { rendszerű díj }\end{array}$ & Késési idő (változó költség) & {$[\mathrm{Ft} / \mathrm{s}]$} \\
\hline
\end{tabular}

ban használt városi modellek figyelembevételével felülvizsgáltuk. Az egyes szakaszokon a szabad áramlási körülmények mellett érvényes eljutási időt $\left(\mathrm{t}_{0}\right)$ a szakasz hosszából és a szabad áramlási sebességből $\left(\mathrm{v}_{0}\right)$ számítja a modell. A kapacitások telítódésével változik az eljutási idő is, ezt az úgynevezett forgalomnagyság-késés (Volume-Delay Function - VDF) függvények írják le. A gyakorlat és a szakirodalmak alapján, illetve igazodva a korábbi kutatásainkhoz is, e célra a FrankWolfe algoritmus függvényét [19] alkalmaztuk:

$$
t_{i}\left(q_{i}\right)=t_{i}^{0}\left(1+0,15\left(\frac{q_{i}}{q_{\max }}\right)^{4}\right)
$$

ahol $t_{i}$ az i-edik szakaszhoz tartozó eljutási idő [s], $t_{i}^{0}$ az i-edik szakaszhoz tartozó eljutási idő forgalommentes állapotban [s], $q_{i}$ az i-edik szakaszhoz tartozó forgalomnagyság [jármü/óra], $q_{\max }$ a vizsgált szakasz kapacitása [jármü/óra].

A közúti ráterhelés az ún. egyensúlyi (equilibrium) eljárással történt, amely Wardrop elvén [20] alapul. Eszerint egyensúlyi körülmények között senki sem tudja csökkenteni utazásainak költségeit útvonala megváltoztatásával, tehát egy adott kiinduló és célpont között használt útvonalak költsége minimális és egyenlö egymással, míg a nem használt útvonalak költsége ennél nagyobb, vagy legjobb esetben is egyenlő ezzel. A ráterhelési számításhoz használt költségek több összetevőből épülnek fel, ezért a helyes megnevezése általánosított utazási költség:

$$
C_{\text {car }}=C_{\text {VoC }}+C_{\text {time }}+C_{\text {toll }}
$$

ahol $C_{c a r}$ : általánosított gépjárműves utazási költség [Ft],

$C_{V O C}: \quad$ a jármüüzemhez kapcsolódó közvetlen költségek (Vehicle Operation Cost) [Ft],

$\mathrm{C}_{\text {time }}$ : $\quad$ az utazási időből származó költségelem [Ft],

$C_{\text {toll }}$ : az alkalmazott útdíjból származó költségtétel [Ft].

$\mathrm{A} \mathrm{C}_{\mathrm{vOC}}$ költségeket a NAV által a gépjármüvek költségelszámolási lehetőségeinek alapvető szabályaiban elöírt tüzelőanyag költség + kilométerenként 9 Ft általános személygépkocsi-normaköltség alapján $35 \mathrm{Ft} / \mathrm{km}$ értékre becsültük. Az utazási idő értékét reprezentáló $\mathrm{C}_{\text {time }}$ tényezőt a Nemzeti Közlekedési Stratégia Összközlekedési forgalmi modellje alapján $3000 \mathrm{Ft}$ /óra értékben vettük figyelembe, a $\mathrm{C}_{\text {toll }}$ tényező pedig vizsgált szcenáriónként változik, alapesetben 0 Ft. A kiinduló és célkörzetekben alkalmazható parkolási költségeket az útválasztás modellezésekor elhanyagoltuk.

A közforgalmú közösségi közlekedési rendszer modellje tartalmazza a legfontosabb budapesti viszonylatokat (városi kötöttpályás viszonylatok, fontosabb autóbuszvonalak). A hozzájuk tartozó menetrendeket a BKK által kiadott GTFS (General Transit Feed Specification) adatbázisból nyertük ki.

A Visum szoftverbe beépített három közforgalmú közösségi közlekedési ráterhelési eljárás közül a követési időköz alapú (headway based) ráterhelést alkalmaztuk. Ez az eljárás a 


\section{Városi közlekedés}

viszonylatok közötti átszállási időt az átlagos követési időkből számolja, és a budapestihez hasonló, sűrű követéssel működő városi hálózatok esetén megfelelő eredményt ad.

\subsection{Igénymodell}

$\mathrm{Az}$ igénymodell létrehozása két fö lépésben történt. Kezdetben nem állt rendelkezésünkre elérhető célforgalmi mátrix, ezért egy saját előállítása volt szükséges, amelyet később kalibrálással tovább pontosítottunk. Az első fö lépésben a hagyományos négylépcsős közlekedési modellezés eszköztárát felhasználva kialakítottunk egy célforgalmi mátrixot, amelynek értékei a kalibráláshoz megfelelő alapot szolgáltattak. A forgalomkeltési adatokhoz a Városkutatás Kft. tanulmányában [9] ismertetett forgalmi modellezési leírás szolgáltatott megfelelő kiindulási pontot, amelyet a modellezés során folyamatosan korrigáltunk. A szétosztás gravitációs modell szerint történt, amelynek alapja a célpontok közötti, forgalom nélküli eljutási idő jelentette ellenállás volt. A négy iterációs lépéssel gyakorlatilag szimmetrikus forgalmi mátrixot sikerült kialakítani. A forgalommegosztás esetében a rendelkezésre álló részletes és pontos adatok hiánya miatt a modal splitre körzettől függően előre meghatározott értékeket alkalmaztunk. Végül az utolsó lépés, a ráterhelés, egy egyszerü eljárással a legrövidebb útra történő terhelés alapján történt, amelyet azonban csak a kezdeti mátrix előállításánál használtunk, a későbbi vizsgálatok során már nem. Az így előállt forgalmakat kiinduló adatnak tekintve végeztük el a második fő lépésben a kalibrálást, amelyhez a Trenecon Kft. keresztmetszeti adatait használtuk fel.

\subsection{HATÁSMODELL}

Az útdíjak hatására a felhasználók válaszreakciója az útvonalválasztás és a modal split módosulásában mutatkozik meg. A létrehozott modellben az általánosított utazási költség reprezentálja az ellenállást a felhasználók számára, amelyben a (2) egyenletben bemutatott módon már az útdíjak is jelen vannak. Az útvonalválasztás modellezését a ráterhelési eljárás végzi el, amelynek így bemenő adatként szükséges megadni az alkalmazott útdíj mértékét. A módváltó utasok számszerüsítéséhez a Trenecon Kft. döntéselőkészítő tanulmányához [11] elvégzett stated preference (SP) vizsgálatok eredményeit használtuk fel. A felvételek során a kikérdezetteknek arra kellett választ adniuk, hogy meghatározott mértékü közlekedési költségnövekedés esetén milyen utazási módot választanának. Mivel a vizsgálatunkban az utazókat alapvetően homogén csoportnak tekintettük, így a munkamotivált utazásokra vonatkozó eredményeket vettük alapul. Az általunk alkalmazott modellben csak a személygépjárműves és a közforgalmú közösségi közlekedési utazásokat vizsgáltuk, ezért az egyéb módon utazókat az SP vizsgálat eredményeiből nem vettük figyelembe. Az eredményekre lineáris függvényeket illesztettünk, amelyek megadták a felhasználók válaszreakcióját a költségek megváltozására.

\section{A MODELL KIÉRTÉKELÉSE}

\subsection{Szcenáriók kialakítása}

Amint az a dimenziókból (1. táblázat) is jól látszik, az egyes stratégiák díjszintjei önmagukban nem összehasonlíthatók, hiszen különböző dimenzióval rendelkeznek, így egységnyi behajtási díj nem ekvivalens az egységnyi távolságalapú vagy időalapú díjjal. Célszerünek tartottuk azonban, hogy a modell egyes szcenáriói egymással összefüggésben álljanak, így a problémát kezelni kellett. Az összehasonlíthatóságot a díjaknak a közlekedési rendszer egyes jellemzőire gyakorolt hatásai alapján vehetjük figyelembe, ezért a teljes egyéni közlekedési igénymátrixra gyakorolt hatást vizsgáltuk. Ugyanakkor a díjszintek meghatározása történhetett volna például meghatározott bevételi szinthez, a kiválasztott szakaszok vagy a területek forgalomnagyságához, eljutási sebességek változásához, vagy akár más paraméterhez igazítva is. Az igénymátrix módosulása azonban jó választásnak tűnt, ugyanis a díj növelésével biztos, hogy szigorúan monoton csökkenni fog a mátrix sarokösszegének értéke. Erre így jó függvénykapcsolat határozható meg. (Míg például a bevétel esetén a növekedés nem evidens, túl nagy díjak esetén senki sem lesz hajlandó megfizetni azokat). 


\section{Városi közlekedés}

\begin{tabular}{|c|c|c|c|c|c|c|}
\hline \multirow{2}{*}{ Díjszint } & \multicolumn{2}{|c|}{ Kordonalapú díj } & \multicolumn{2}{|c|}{ Távolságalapú díj } & \multicolumn{2}{|c|}{ Időalapú díj } \\
\hline & Szcenárió jele & Díj [Ft/behajt.] & Szcenárió jele & Díj [Ft/km] & Szcenárió jele & Díj [Ft/s] \\
\hline Útdíj nélküli eset & K0 & 0 & D0 & 0 & T0 & 0 \\
\hline 2\%-os csökkenés & K2 & 359,259 & D2 & 42,569 & $\mathrm{~T} 2$ & 0,945 \\
\hline 4\%-os csökkenés & K4 & 718,518 & D4 & 85,137 & $\mathrm{~T} 4$ & 2,145 \\
\hline 6\%-os csökkenés & K6 & 1077,777 & D6 & 127,706 & T6 & 4,172 \\
\hline
\end{tabular}

$\mathrm{Az}$ elözetes vizsgálatot követően a részletes vizsgálatba bevont szcenáriók díjszintjeit az igénymátrix 2, 4 és $6 \%$-os csökkenéséhez igazítottuk, amelyeket részletesen a 2 . táblázat mutat be.

\subsection{Közúti egyéni közlekedési szegmens}

A rendszerben az összes egyéni közúti közlekedési igény a vizsgált változatok esetében nem mutat eltérést, hiszen az egyes szcenáriókat ennek változásából levezetve definiáltuk, a közúti igények 2, 4 és 6 százalékos csökkenéséhez igazítva. Ugyanakkor az igényeket alábontva már megfigyelhető némi eltérés, amely főként a díjstruktúrák eltérő müködési mechanizmusából fakad (pl. a kordonos rendszer nem bünteti a tisztán belső utazásokat, míg a többi rendszer igen). Az eredményeket az 1. ábra mutatja be.

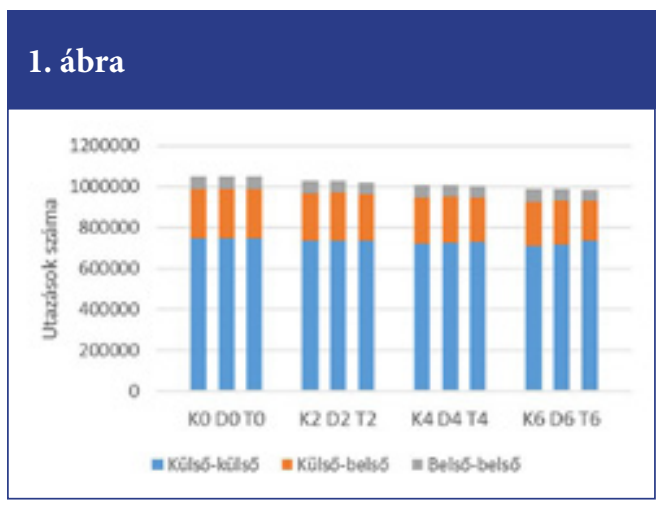

A 2. ábra alapján megállapítható, hogy a teljes rendszerre nézve a kordonalapú és a távolságalapú díjak nem hoznak szignifikáns változást az utazási idők értékében, azonban időalapú díjazás esetén jelentős a növekedés. Egyértelmü és vizsgálatunk által is bizonyított, hogy a védett területen kívülre terelődő forgalom egyrészt nagy kerülőt vállal be a díjak elkerüléséhez, másrészt az itt megjelenő többletterhelés fennakadásokat okozhat, ez pedig a forgalom lassulását eredményezheti.

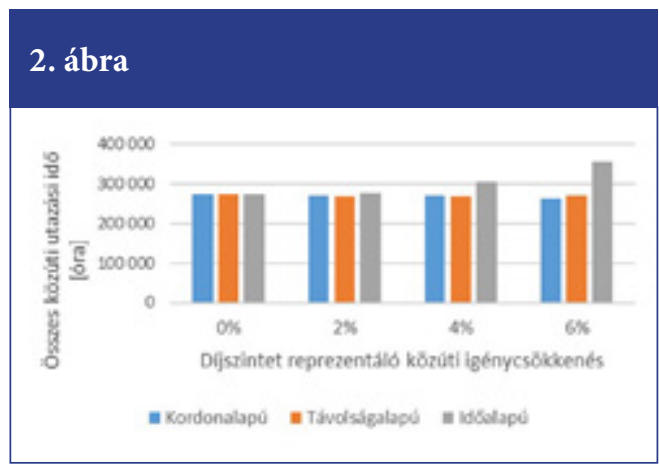

A 3. ábra alapján ugyanakkor látható az is, hogy a védett területen belül minden díjstruktúra esetén egyre kevesebb időt töltenek az egyéni gépjárművel közlekedők.

\section{3. ábra: Közúti igények változása}

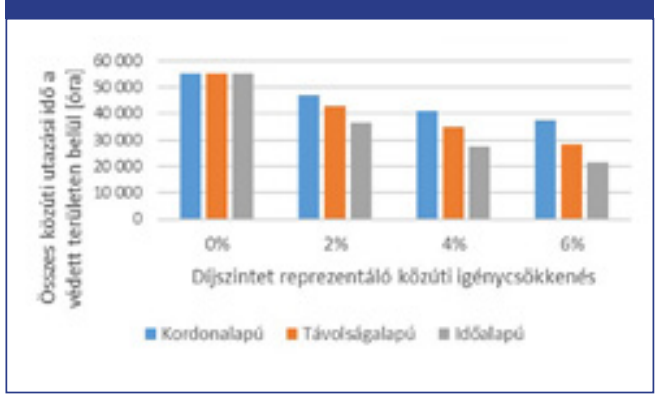




\section{Városi közlekedés}

Az utazási idők számottevő része származik az ún. késési (vagy torlódási) időkből, amelyek a forgalommentes állapothoz képesti időtöbbletet jelentik, és a már bemutatott forgalomnagyság-késés függvény segítségével számolhatók. A 4. ábrából látható, hogy a teljes hálózatra nézve az útdíj hatása negatív, ugyanis a késési idők a díjszint növelésével összhangban emelkednek, leglátványosabban az időalapú díjazásnál, mivel a fizetős területet körülvevő gyürük ebben az esetben telítődnek leginkább. Ez rendkívül megnöveli a torlódási időveszteséget ezeken a szakaszokon.

\section{4. ábra: Napi összes közúti utazási idő alakulása}

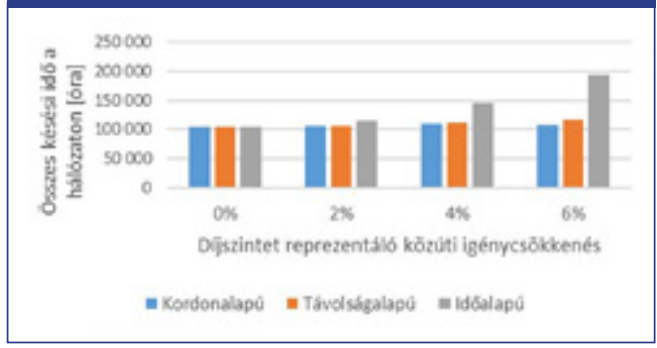

A belső védett területre koncentrálva az 5. ábra megmutatja, hogy az időveszteségek jelentősen csökkennek. Már a legalacsonyabb díjak mellett is számottevő a csökkenés, a legmagasabb díjszinten pedig távolságalapú és időalapú díjstruktúra esetén gyakorlatilag minimális a megmaradó késési idő.

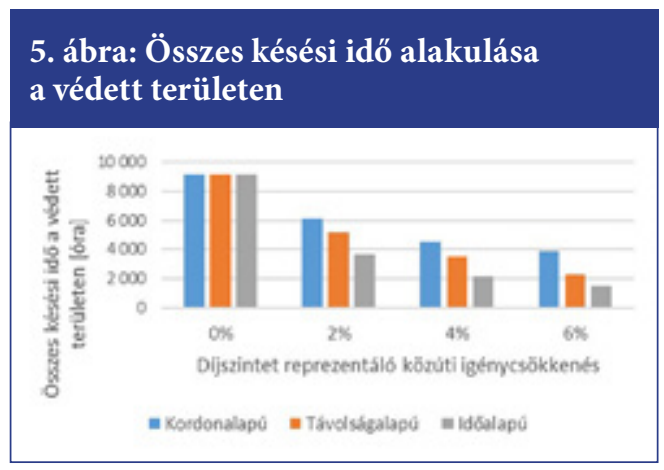

A HBEFA modell által vizsgálható szennyezők közül a szén-dioxid kibocsátást vettük figyelembe, ami a felhasznált tüzelőanyag meny- nyiségének a függvénye. A 6. ábrából látható, hogy a várakozásoknak megfelelően mindegyik díjstruktúra kedvezően hat a védett területen az emisszióra. A leghatékonyabb ebben a tekintetben az időalapú rendszer, amit a távolságalapú követ. Legkisebb változás a kordonalapúval érhető el.

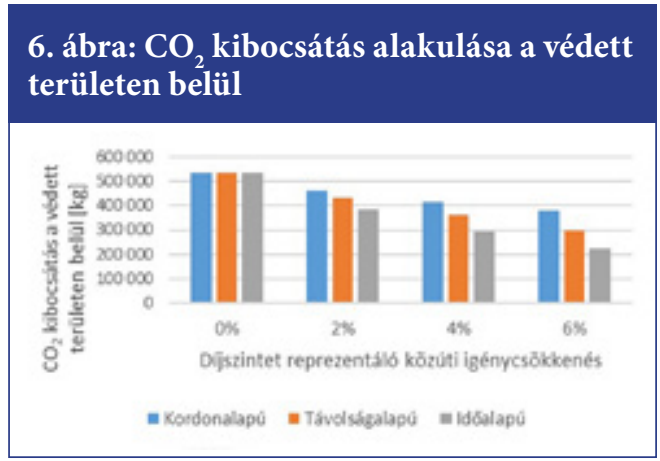

A 7. ábrából megállapítható, hogy egy bizonyos díjszintig a teljes hálózaton is csökken az emisszió, díjstruktúrától függetlenül. A legmagasabb díjszinteknél azonban a korábban bemutatottaknak megfelelően az időalapú rendszer a zónán kívüli útszakaszokon rendkívül kedvezőtlen forgalmi helyzetet teremt, ami a teljes hálózatra nézve rontja a rendszer hatékonyságát, de már közepes díjszint esetén is alulmarad a másik két stratégiával szemben.

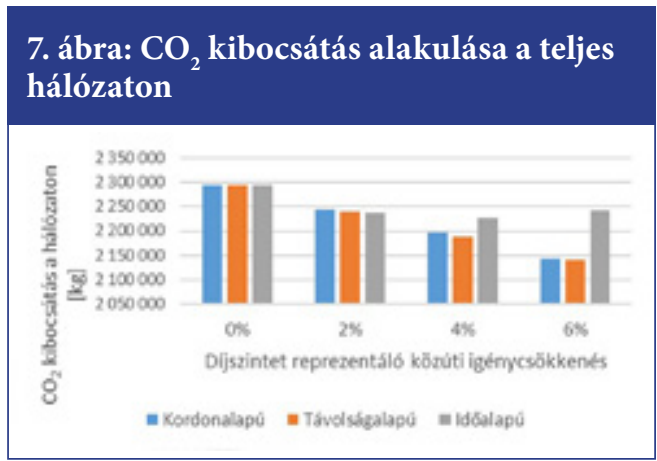

A modellben a közforgalmú közösségi közlekedési rendszer minden vizsgált szcenárió esetén fix, így a személygépjármüvekből autóbuszra szálló utasok a közforgalmú közösségi közlekedés oldalán nem generálnak többletemissziót. 
A közforgalmú közösségi közlekedés kínálatának bővítésével azonban lehetőség lenne vizsgálni a módváltó utasok esetén a károsanyag-kibocsátás mérlegét, ami a jelenlegi modell keretein azonban már túlmutat, és a kutatás folytatásakor jelent továbbfejlesztési lehetőséget.

\subsection{A közforgalmú közösségi közlekedési szegmens}

A közforgalmú közösségi közlekedési igények alakulása - a módváltó utasok miatt - a közúti igények alakulásával (1. ábra) ellentétes képet mutat. A kordonalapú útdíjak inkább a hosszabb utazások esetén hoznak változást a modal splitben, amelyet a 8 . ábra is alátámaszt: láthatóan ennél nő meg leginkább az utaskilométer teljesítmény.

\section{8. ábra: Napi utaskilométer teljesítmény alakulása (forrás: saját szerkesztés)}

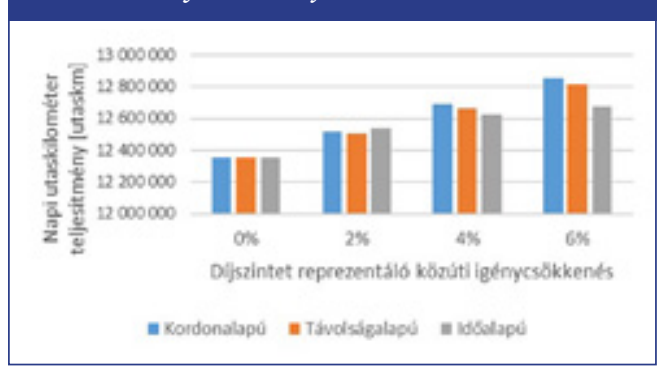

\section{AZ EREDMÉNYEK ÖSSZEGZÉSE ÉS A KONKLÚZIÓ}

Számos jellemző vizsgálatánál szembeötlő, hogy az időalapú útdíj mennyivel jobban teljesít a többi rendszerhez képest. Szinte kivétel nélkül igaz ez azokra az esetekre, ahol a belső, védett terület forgalmi jellemzőit vizsgáltuk. Ugyanakkor láthatók a rendszer hátrányai is. Árnyalja a képet, ha a fontosabb jellemzőket nem csak a védett területre, hanem a teljes vizsgált rendszerre tekintjük. Ekkor feltünik, hogy a külső területen olyan mértékü többletforgalom jelenik meg, hogy a teljes rendszerre nézve összességében romlanak a vizsgált mutatók (pl. futásteljesítmény, sebesség). Ennek is betudható, hogy a rendszert a gyakorlatban nem alkalmazzák. Annak idején a londoni „dugódíj” bevezetését megalapozó vizsgálatok is elvetették [20], illetve kutatások is kimutatták [21], hogy a járművezetők kockázatvállalási hajlandósága megnő annak érdekében, hogy minél hamarabb elhagyhassák a fizetős területet.

A kordonalapú díjfizetés a legtöbb vizsgálati szempont esetében a sor végén található, mint legkevésbé hatékony díjstratégia. Tény azonban, hogy a gyakorlati megvalósítás költsége - amely egyébként döntéshozói szinten nyilvánvalóan fontos tényező - nem képezte a vizsgálat tárgyát, pedig ebben a tekintetben biztosan élenjáró lett volna. Legtöbb esetben a kordonalapúnál hatékonyabban teljesít a távolságalapú díjrendszer, ráadásul az időalapúval ellentétben kirívó hátrányai sincsenek.

\section{FELHASZNÁLT IRODALOM}

[1] Vickrey, W. S.: Pricing in urban and suburban transport. American Economic Review, Vol. 53, No. 2, pp 452-465, 1963.

[2] Smeed, R. J.: Road pricing: the economic and technical possibilities. HMSO, 1964.

[3] Pigou, A. C.: The economics of welfare. MacMillan, 1920.

[4] de Palma, A.; Lindsey, R.: Traffic congestion pricing methodologies and strategies. Transportation Research Part C, 19(6):13771399, 2011. DOI: http://doi.org/chnmd8

[5] Erhart Sz.: A budapesti közlekedési dugók okai és következményei. Közgazdasági Szemle, Vol. 54, No. 5, pp. 435-458, 2007.

[6] Juhász Mattias, Tóth László: A városi útdíj lehetősége Budapesten (Élhető Város), Közlekedéstudományi szemle, 2010. (60. évf.) 1. sz. 12-19. old.

[7] Monigl János, Berki Zsolt, Nagy Endre, Koren Tamás, Ujhelyi Zoltán: Behajtási díj hatásának modellvizsgálata Budapest belvárosi területére vonatkozóan, Városi közlekedés, 2003. (43. évf.) 2. sz. 81-91. old.

[8] Monigl János, Berki Zsolt, Ujhelyi Zoltán, Ábel Melinda, Antal Istvánné: Behajtási díjak forgalmi hatásainak vizsgálata $\mathrm{Bu}$ dapest belső térségében, Városi közlekedés, 2009. (49. évf.) 6. sz. 295-309. old.

[9] Városkutatás Kft.: Hatékony közlekedésmenedzsment Budapesten. A fövárosi behajtási díj indokoltságának, bevezethetöségének és zónarendszerének vizsgálata. Koncepció. Budapest, 2008. 


\section{Városi közlekedés}

[10] Városkutatás Kft.: A fővárosi személyforgalmi behajtási díj megvalósíthatásának elözetes vizsgálata. Budapest, 2009.

[11] Budapesti Közlekedési Központ, TreneconCOWI: Fővárosi személyforgalmi behajtási díj bevezetése. Döntéstámogató tanulmány. Budapest, 2013.

[12] May, A. D.; Liu, R.; Shepherd, S.P.; Sumalee, $A$.: The impact of cordon design on the performance of road pricing schemes. Transport Policy, Vol. 9, No. 3, pp. 209-220, 2002. DOI: http://doi.org/csdmch

[13 Verhoef, E. T.: Second-best Congestion Pricing in General Static Transportation Networks with Elastic Demands. Regional Science and Urban Economics, Vol. 32, No. 3, pp. 281-310, 2002. DOI: http://doi.org/cjwmj4

[14] Zhang, L.; Liu, H.; Sun, D.: Comparison and optimization of cordon and area pricings for managing travel demand. Transport, Vol. 29, No. 3, pp 248-259, 2014. DOI: http:// doi.org/csww

[15] May, A. D.; Milne, D. S.: Effects of alternative road pricing systems on network performance. Transportation Research Part A, Vol. 34, No. 6, pp. 407-436, 2000. DOI: http://doi.org/dw27vr

[16] May, A. D.; Milne, D. S.: The impact on network performance of drivers' response to alternative road pricing schemes. In: Road Pricing: Theory and Evidence, Szerk: Georgina Santos, Elsevier, pp. 61-85, 2004.

[17] Börjesson, M.; Eliasson, J.; Hugosson, M. B.; Brundell-Freij, K.: The Stockholm congestion charges - 5 years on. Effects, acceptability and lessons learnt. Transport Policy, Vol. 20 (March 2012), pp. 1-12, 2012. DOI: http://doi.org/dg2rdv

[18] Tóth T.: Kordonalapú és távolságalapú városi útdíjfizetési rendszer budapesti kialakításának összehasonlítása. Tudományos Diákköri Konferencia, Budapesti Müszaki és Gazdaságtudományi Egyetem, Közlekedésmérnöki és Jármümérnöki Kar, Közlekedésgazdasági szekció, 2014.

[19] Wardrop, J. G.: Some theoretical aspecrs of road traffic research. Proceedings of the Institution of Civil Engineers. Vol. 36, No. 1, pp. 325-362, 1952.

[20] Richards, M.; Gilliam, C.; Larkinson, J.: The London congestion charging research programme: 1. The programme in overview. Traffic Engineering and Control, 37, pp. 660-671, 1996.

[21] Bonsall, P. W.; Palmer, I. A.: Do time-based road-user charges induce risk tasking? Results from a driving simulator. Traffic Engineering and Control, 38, pp. 200-203, 1997.

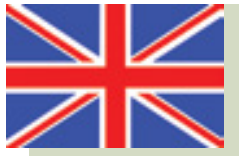

\section{Investigating the Impact of Different Urban Toll Structures}

This paper shows a comparison of several potential urban toll strategies. From a number of available theoretical solutions, basically, the cordon-based system was examined in more detail in regards of Budapest. This is why we investigated in comparison to this the characteristics of the distance-based, time-based and time delay-based payment strategies. The study was carried out using a macroscopic traffic model, and in addition to the traffic and emission characteristics of passenger cars, we also examined the characteristics of the public transport segment.

\section{Untersuchung der Aus- wirkungen unterschiedlicher städtischer Mautstrukturen}

Im diesem Artikel es werden einen Vergleich verschiedene mögliche städtische Mautstrategien verglichen. Aus einer Reihe verfügbarer theoretischer Lösungen wurde in Budapest grundsätzlich das Kordon-basierte System eingeführt, deshalb wurde es genauer untersucht. Deshalb haben wir im Vergleich damit die Eigenschaften der entfernungsbasierten, zeitbasierten und zeitverzögerungsbasierten Zahlungsstrategien untersucht. Die Studie wurde unter Verwendung eines makroskopischen Verkehrsmodells durchgeführt, und zusätzlich zu den Verkehrs- und Emissionseigenschaften von Personenkraftwagen-Verkehr untersuchten wir auch die Eigenschaften des öffentlichen Transportsektors. 